\title{
Efficacy of various chemotherapeutic agents on the growth of Spironucleus vortens, an intestinal parasite of the freshwater angelfish
}

\author{
Somboon Sangmaneedet, Stephen A. Smith* \\ Department of Biomedical Sciences and Pathobiology, Virginia-Maryland Regional College of Veterinary Medicine, \\ Virginia Polytechnic Institute and State University, Blacksburg, Virginia 24061, USA
}

\begin{abstract}
Seven chemotherapeutic agents (dimetridazole, metronidazole, pyrimethamine, albendazole, fenbendazole, mebendazole and magnesium sulfate) were examined for growth inhibition on the cultivation of Spironucleus vortens. Dimetridazole and metronidazole were effective in inhibiting the parasite's growth. At concentrations of $1 \mu \mathrm{g} \mathrm{ml} \mathrm{m}^{-1}$ or higher, both dramatically decreased numbers of parasites. At $24 \mathrm{~h}$ exposure, $33 \%$ of parasites were inhibited when exposed to dimetridazole or metronidazole at concentrations of 2 and $4 \mu \mathrm{g} \mathrm{ml}^{-1}$, respectively. Dimetridazole at $4 \mu \mathrm{g} \mathrm{ml}^{-1}$ or higher concentrations decreased the number of organisms to $50 \%$ or less after $48 \mathrm{~h}$ exposure. During the same period of time, the numbers of parasites decreased to $50 \%$ or less when exposed to metronidazole at $6 \mu \mathrm{g} \mathrm{m} \mathrm{m}^{-1}$ or higher. Pyrimethamine at concentrations of 1 to $10 \mu \mathrm{g} \mathrm{m} \mathrm{m}^{-1}$ was not effective in inhibiting the parasite's growth. Albendazole and fenbendazole at concentrations of 0.1 and $0.5 \mu \mathrm{g} \mathrm{ml}^{-1}$ were similar in inhibiting the growth of the organism. Both compounds suppressed parasite growth at concentrations of $1.0 \mu \mathrm{g} \mathrm{ml}^{-1}$ or higher after $24 \mathrm{~h}$ exposure. Mebendazole inhibited the parasite's growth at concentrations of $0.5 \mu \mathrm{g} \mathrm{ml}^{-1}$ or higher. At $72 \mathrm{~h}$ exposure. 45 to $50 \%$ of the parasites were inhibited when exposed to mebendazole at concentrations higher than $0.5 \mu \mathrm{g} \mathrm{ml^{-1 }}$ Magnesium sulfate at concentrations of $70 \mathrm{mg} \mathrm{ml}^{-1}$ or higher also suppressed the growth of parasites after 24 h exposure. These results indicate that dimetridazole, metronidazole and mebendazole are the most effective chemotherapeutic agents in vitro at inhibiting the growth of $S$. vortens.
\end{abstract}

KEY WORDS: Diplomonad Spironucleus $\cdot$ Treatment $\cdot$ Chemotherapy $\cdot$ Angelfish

\section{INTRODUCTION}

Hexamita and Spironucleus are diplomonad flagellates frequently found in the digestive tract of both freshwater and saltwater fish (Kulda \& Lom 1964, Ferguson 1979, Mo et al. 1990). These motile flagellates can cause cellular damage in the intestinal tract of infected fishes and heavy infections may interfere with normal growth of the host (Yasutake et al. 1961). They often cause disease when the host has a low resistance or is adversely affected by some predisposing factors such as inadequate nutrition, low oxygen content, poor sanitation or overcrowding (Lom \& Dyková 1992). They have been reported as pathogens causing enteritis and mortalities in salmonids, cyprinids and orna-

\footnotetext{
·Addressee for correspondence.E-mail: stsmith7@vt.edu
}

mental tropical aquarium fish (Sommerville 1981, Gratzek 1988, Woo \& Poynton 1995). Thus, treatment and control of these organisms are important in both the foodfish and tropical fish industry. Most studies of chemotherapeutic agents for this group of parasites have been evaluated using Hexamita sp., a parasite of salmonids (Yasutake et al. 1961, McElwain 1968, Tojo \& Santamarina 1998). Although there is a report of chemotherapeutic activity on Spironucleus muris, a parasite of the mouse intestine (Oxberry et al. 1994), there are no published reports of chemotherapeutic efficacy on $S$. vortens of fish.

Metronidazole, 1-(2-hydroxy ethyl)-2-methyl-5-nitroimidazole, is the active compound of nitroimidazole used in the treatment of infections caused by anaerobic bacteria and protozoa (Amon et al. 1978, Baines 1978. McLean et al. 1984). The drug is rapidly absorbed from 
the gastrointestinal tract and is effective against obligate anaerobic organisms having an active hydrogenase (Church et al. 1996). It has been applied frequently in the treatment of flagellate infections causing urogenital trichomoniasis and giardiasis in humans (Catchpool 1980). In addition, metronidazole $\left(\right.$ Flagyl $\left.^{(}\right)$and metronidazole-related compounds (Ipropran $^{*}$ and Emtryl ${ }^{+}$) have been used in the treatment of hexamitiasis in trout, ornamental fish and several species of cichlids (Gratzek 1983). Therefore, metronidazole and dimetridazole, a metronidazole-related compound, may be effective in the treatment of Spironucleus vortens, an aerotolerance anaerobe in angelfish.

The benzimidazole anthelmintics is another group of chemotherapeutics that has been shown to be effective against intestinal protozoa such as Giardia lamblia (Edlind et al. 1990, Bell et al. 1993), G. duodenalis, Trichomonas vaginalis and Spironucleus muris (Oxberry et al. 1994). Being less absorbable, albendazole and mebendazole were 30 to 50 times more active than metronidazole (Edlind et al. 1990). Albendazole has also been reported to be successful in the treatment of Hexamita salmonis infection in rainbow trout (Tojo \& Santamarina 1998). The target of benzimidazoles in Giardia sp. is a structure called $\beta$-tubulin (Edlind et al. 1990). The internal structures of $S$. vortens such as recurrent flagella, peripheral ridges and body (beneath the cell surface) are also supported by microtubules (Poynton et al. 1995). Therefore, benzimidazoles may be effective in the treatment of $S$. vortens.

Pyrimethamine (2,4-diamino-5-p-chlorophenyl-6ethylpyrimidine) is an antiprotozoal drug commonly used for antimalarial activity and the treatment of toxoplasmosis (Pratt \& Fekety 1986, Rosenblatt 1992, Bradyley \& Marciano-Cabral 1995). Pyrimethamine in combination with sulfadiazine has also been used in the successful treatment of chronic intestinal coccidiosis in man (Trier et al. 1974). The drug is chemically related to trimethoprim and is slowly absorbed from the gastrointestinal tract (Catchpool 1980). Parasiticidal efficacy of pyrimethamine is due to inhibition of the synthesis of dihydrofolate reductase which catalyzes the conversion of dihydrofolate into tetrahydrofolate in organisms (Pratt \& Fekety 1986, Bradyley \& MarcianoCabral 1995). The folate coenzyme, tetrahydrofolate, is necessary in the reactions involved in purine, pyrimidine and amino acid synthesis (Pratt \& Fekety 1986, Bradyley \& Marciano-Cabral 1995). Thus, organisms exposed to pyrimethamine are killed due to a deficiency of the folate coenzyme that results in the inhibition of cell division (Catchpool 1980). With the energetic self-division of Spironucleus vortens, pyrimethamine may be effective in the treatment of spironucleosis.
Unlike the previously discussed chemotherapeutic agents, magnesium sulfate $\left(\mathrm{MgSO}_{4}\right.$, Epsom salt) is frequently used as purgative. It has been used for the treatment of parasitic diseases, especially luminal parasite infestations. When the magnesium salts reach the intestine, magnesium ions cause the release of cholecystokinin, which increases peristaltic activity of the intestine (Jenkins 1988). Increased movement then helps the host to expel or decrease the number of parasites in the intestine. Free flagellates of diplomonads are the most commonly encountered stage found in the fish's intestine (Woo \& Poynton 1995) and are capable of disseminating to other tissues during stressful conditions of the host (Molnár 1974). Therefore, it was hypothesized that magnesium sulfate may also be helpful in reducing the number of parasites in the intestine of the fish.

In the present study, 7 different chemotherapeutic compounds were examined at various concentrations for any effect on the ability of the parasite Spironucleus vortens to survive and reproduce in an in vitro culture system.

\section{MATERIALS AND METHODS}

Parasite cultivation. Spironucleus vortens were cultivated in TYI-S-33 medium (ATCC, Cat. No. 350-x) at $\mathrm{pH}$ 6.8. The antibiotics, penicillin (2000 $\left.\mathrm{U} \mathrm{ml}^{-1}\right)$ and gentamicin $\left(50 \mu \mathrm{g} \mathrm{ml} \mathrm{m}^{-1}\right)$, were added to the medium during routine culture, but were omitted during experimental treatments. The organisms were cultivated in a sterile flask and placed in an incubator at $25^{\circ} \mathrm{C}$ without light.

Parasite cell counting. The concentration (average cell number $\mathrm{ml}^{-1}$ ) of Spironucleus vortens in the culture medium was determined daily by automatic cell counter (CASY 1 i model TTC, Schärfe System, GmbH, Germany). The parasite suspension was gently mixed, aliquots of either 5 or $10 \mu \mathrm{l}$ were added into counter containers with $10 \mathrm{ml}$ PBS, and the resulting cell mixture analyzed.

Growth inhibition assay. All chemicals, except magnesium sulfate, were prepared at different concentrations by dissolving in dimethyl sulfoxide (DMSO, Sigma Chemical Co., St. Louis, MO, USA). Concentrations of Epsom salt $\left(\mathrm{MgSO}_{4}\right)$ were prepared by dissolving in fresh culture medium. Chemotherapeutic agents were divided into 3 separate testing groups. Chemicals in the first group were dimetridazole, metronidazole and pyrimethamine; the second group were albendazole, fenbendazole and mebendazole; and the last group was magnesium sulfate. Control groups were established for each chemotherapeutic testing group, and an additional group was established to determine 
the effect of DMSO (solvent) on the parasite's growth All cultures were established in triplicate in sterile $4 \mathrm{ml}$ screw-capped glass tubes which were placed in a thermo-regulated incubator at $25^{\circ} \mathrm{C}$. The average number of parasites (cells $\mathrm{ml}^{-1}$ ) was determined every 24 h until no parasites were observed alive.

Dimetridazole, metronidazole and pyrimethamine were tested at concentrations of $1,2,4,6,8$ and $10 \mu \mathrm{g}$ $\mathrm{ml}^{-1}$. Log-phase Spironucleus vortens concentration of $5.44 \times 10^{6}$ cells $\mathrm{ml}^{-1}$ was established on the first day of cultivation with $2 \mathrm{ml}$ of culture medium per vial and incubated at $25^{\circ} \mathrm{C}$ without light. Albendazole, fenbendazole and mebendazole were examined at concentrations of $0.1,0.5,1.0,1.5,2.0,2.5$ and $3.0 \mu \mathrm{g} \mathrm{m}^{-1}$. Logphase $S$. vortens concentration of $4.23 \times 10^{6}$ cells ml $\mathrm{m}^{-1}$ was established on the first day of cultivation with $2 \mathrm{ml}$ of culture medium per vial and incubated as described. Magnesium sulfate was prepared at concentrations of $5,10,20,30,40,50,60,70,80,90$ and $100 \mathrm{mg} \mathrm{ml}^{-1}$. Logphase parasites were established in $2 \mathrm{ml}$ of culture medium per vial at $3.78 \times 10^{6}$ cells $\mathrm{ml}^{-1}$ on the first day of cultivation. The cultures were incubated as described. DMSO (solvent) was examined for its effect on the parasite's growth. Cultures with different concentrations of DMSO $(0.025,0.05,0.10,0.15,0.20$ and $0.25 \%$ ) were established and examined along with the experiment of dimetridazole, metronidazole and pyrimethamine.

\section{RESULTS}

Growth of Spironucleus vortens at different concentrations of DMSO are shown in Fig. 1. DMSO dissolved in the artificial medium at concentrations of 0.025 to $0.25 \%$ minimally affected the growth of $S$. vortens

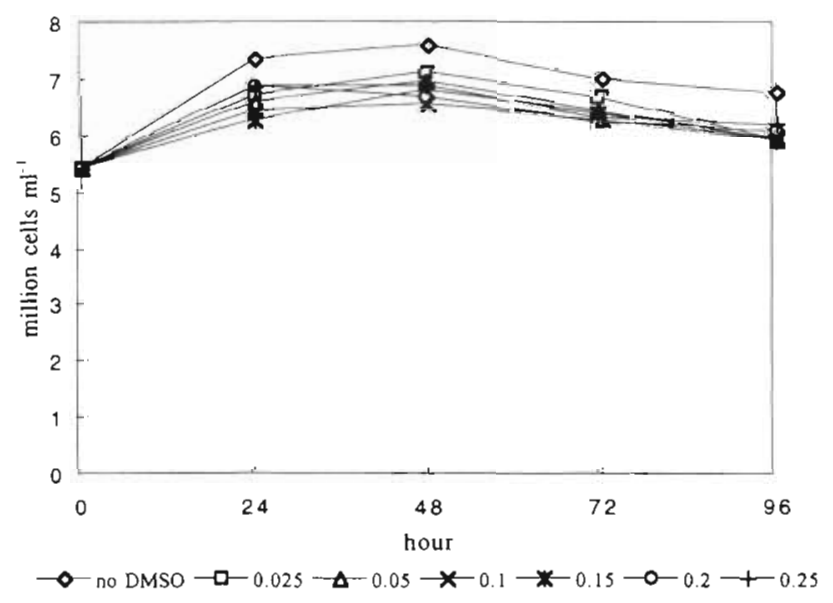

Fig. 1. Spironucleus vortens. Growth in different concentrations $(\%)$ of dimethyl sulfoxide (DMSO)

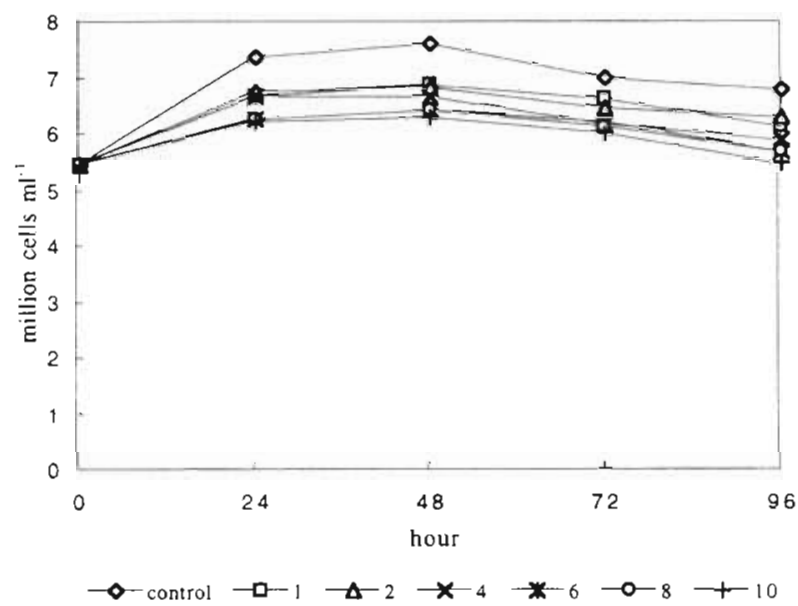

Fig. 2. Spironucleus vortens. Growth in different concentrations ( $\left.\mu \mathrm{g} \mathrm{m}^{-1}\right)$ of pyrimethamine

Compared to the growth of organisms in cultures with DMSO, pyrimethamine at concentrations of 1 to $10 \mu \mathrm{g}$ $\mathrm{ml}^{-1}$ also did not inhibit the growth of the parasites (Fig. 2). Under microscopic observation, the conditions (morphology and movement) of organisms in cultures with DMSO or pyrimethamine were not different from those of the control (medium only) cultures.

Dimetridazole weakly inhibited the organism's growth at a low concentration (1 $\mu \mathrm{g} \mathrm{m}^{-1}$ ) (Fig. 3). However after $24 \mathrm{~h}$ incubation with $2 \mu \mathrm{g} \mathrm{ml}^{-1}$ dimetridazole, $33.46 \%$ of the parasites displayed inhibited growth. The percentages of parasites which were inhibited from growing were not significantly different from those exposed to dimetridazole at $4 \mathrm{\mu g} \mathrm{ml}^{-1}$ or higher concentrations. More than $50 \%$ of the organisms were killed after $48 \mathrm{~h}$ exposure to dimetridazole at a concentration of $4 \mu \mathrm{g} \mathrm{ml}^{-1}$ or higher. Under microscopic observation, a large number of

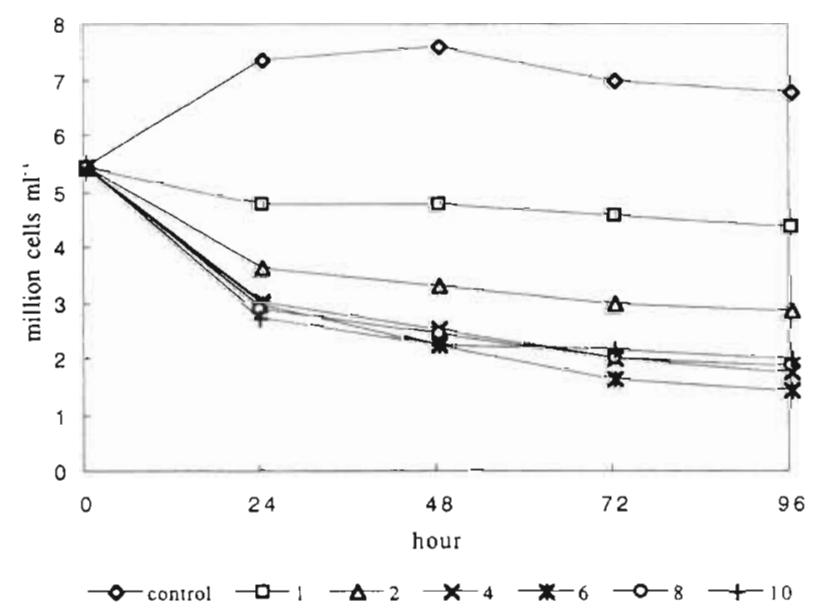

Fig. 3. Spironucleus vortens. Growth in different concentrations ( $\mathrm{kg} \mathrm{ml}^{-1}$ ) of dimetridazole 


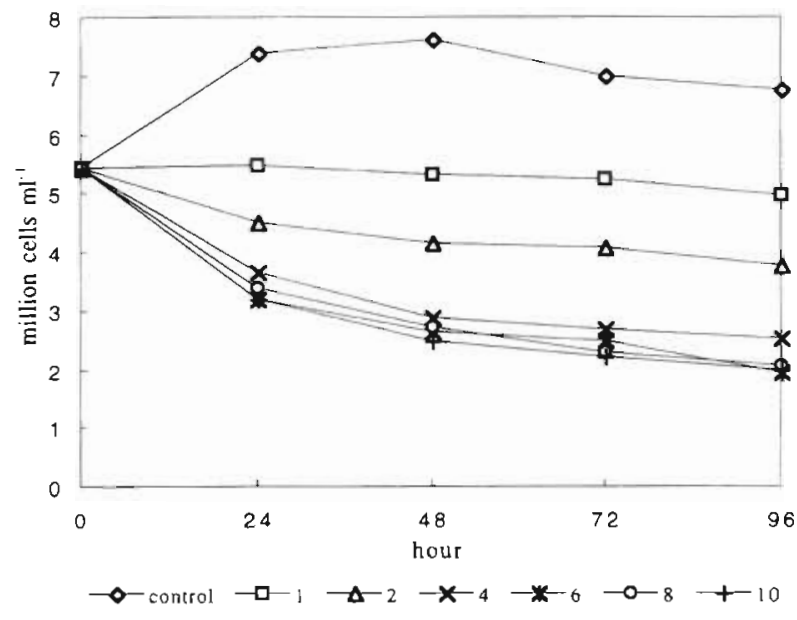

Fig. 4. Spironucleus vortens. Growth in different concentrations $\left(\mu \mathrm{g} \mathrm{m}^{-1}\right)$ of metronidazole

trophozoites of Spironucleus vortens exposed to dimetridazole were not in their normal pyriform shape, but were multinucleated trophozoites that were larger in size with numerous flagella.

Growth inhibition of Spironucleus vortens by metronidazole was similar to that observed with dimetridazole (Fig. 4). At 24 h exposure, 33.09\% of parasites were dead after incubation with $4 \mu \mathrm{g} \mathrm{ml}^{-1}$. Metronidazole at concentrations higher than $4 \mu \mathrm{g} \mathrm{ml}^{-1}$ decreased the number of parasites by more than $50 \%$ at $48 \mathrm{~h}$ exposure. Compared to dimetridazole, metronidazole was less effective in decreasing the number of parasites at the same concentration and exposure period. Metronidazole $\left(2 \mu \mathrm{g} \mathrm{ml}^{-1}\right.$ ) killed only $17.46 \%$ of the parasites, whereas $33.46 \%$ of the organisms were killed with dimetridazole at the same concentration and same exposure period ( $24 \mathrm{~h}$ ).

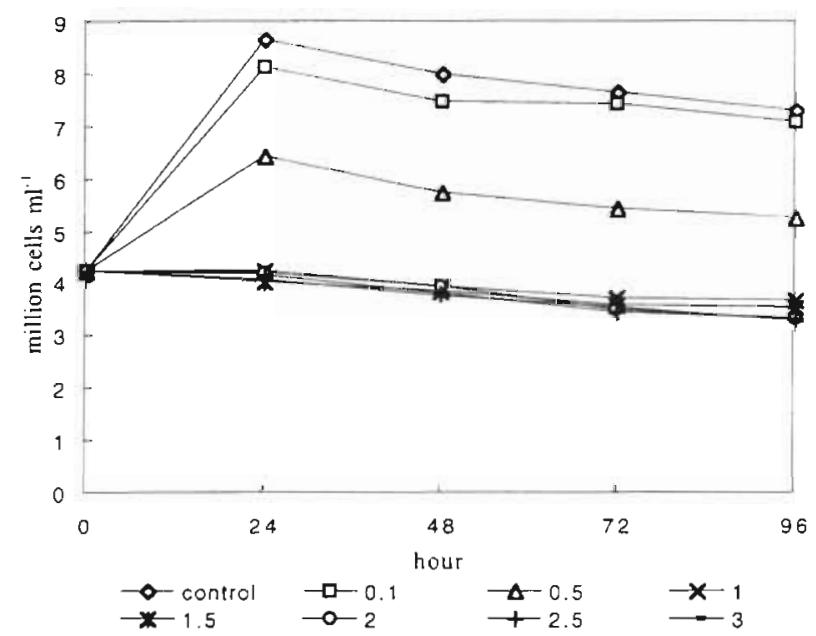

Fig. 5. Spironucleus vortens, Growth in different concentrations ( $\mu \mathrm{g} \mathrm{mil}^{-1}$ ) of albendazole

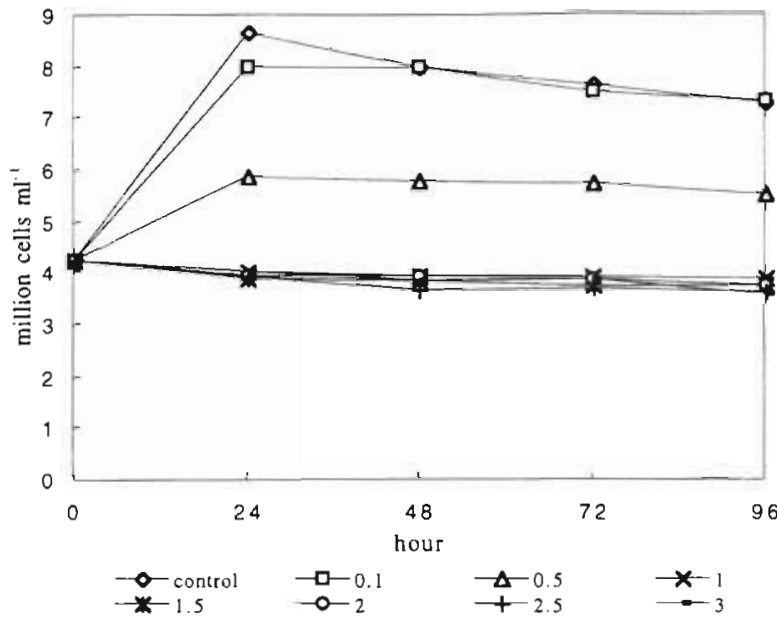

Fig. 6. Spironucleus vortens. Growth in different concentrations $\left(\mu \mathrm{g} \mathrm{ml}^{-1}\right)$ of fenbendazole

Growth inhibitions of Spironucleus vortens by albendazole and fenbendazole are shown in Figs. 5 \& 6, respectively. Albendazole and fenbendazole failed to inhibit the parasite's growth at concentrations less than $0.5 \mu \mathrm{g} \mathrm{ml}^{-1}$. At higher concentrations ( 1 to $3 \mu \mathrm{g} \mathrm{ml}^{-1}$ ), both albendazole and fenbendazole minimally inhibited the growth of the organism. Compared to albendazole and fenbendazole, mebendazole (Fig. 7) was more effective in inhibiting the parasite's growth. Mebendazole inhibited the parasite's growth at concentrations of $0.5 \mu \mathrm{g} \mathrm{ml}^{-1}$ or higher. The numbers of parasites gradually decreased throughout the cultivation period when exposed to an increasing concentration of mebendazole, with the greatest period of growth inhibition seen after $24 \mathrm{~h}$ exposure. After $72 \mathrm{~h}$ of exposure, approximately 45 to $50 \%$ of the parasites were killed when incubated with mebendazole (1.0 to $3.0 \mu \mathrm{g} \mathrm{ml}^{-1}$ ).

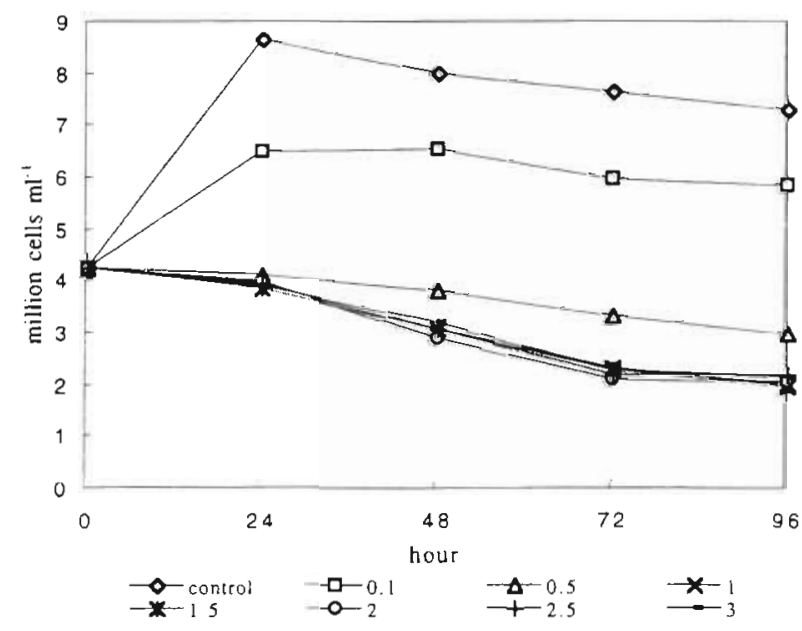

Fig. 7. Spironucleus vortens. Growth in different concentrations $\left(\mu \mathrm{g} \mathrm{ml}^{-1}\right.$ ) of mebendazole 


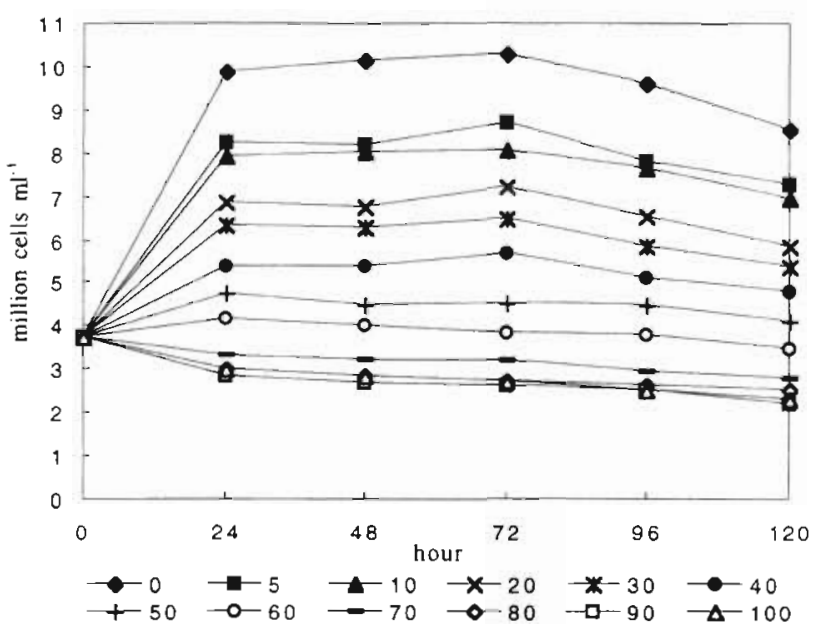

Fig. 8. Spironucleus vortens. Growth in different concentrations $\left(\mu \mathrm{g} \mathrm{ml}^{-1}\right.$ ) of $\mathrm{MgSO}_{4}$

Growth of Spironucleus vortens in different concentrations of magnesium sulfate are shown in Fig. 8. Epsom salt at all concentrations (5 to $100 \mathrm{mg} \mathrm{ml}^{-1}$ ) affected the growth of $S$. vortens. The average numbers of parasites at concentrations of 5 to $60 \mathrm{mg} \mathrm{ml}^{-1}$ gradually increased with exposure time, but gradually decreased at $70 \mathrm{mg} \mathrm{ml}^{-1}$ or higher of $\mathrm{MgSO}_{4}$ after $24 \mathrm{~h}$ exposure.

\section{DISCUSSION}

Spironucleus vortens, an aerotolerance anaerobe, are highly energetic flagellate protozoa. They are normally pyriform in shape and they actively move in a forward direction in the culture medium. In the present study $S$. vortens were cultivated and examined in an artificial medium with different types and concentrations of chemotherapeutic agents. Nitroimidazole, particularly metronidazole, is the most widely prescribed drug in the treatment of anaerobic protozoa (Amon et al. 1978, Edwards 1980, Church et al. 1996). Compounds in this group enter cells and are accumulated inside the cells by passive diffusion without an active transport process (Müller 1983, Chapman et al, 1985). Their intermediate products, the reduced nitro-group forms, function as a short-lived cytotoxic effect, and the accumulation of these intermediates enhances the rate of entry of the chemical into the susceptible cells (Edwards 1980). Metronidazole also reduced the homogeneous material within the cytoplasm and caused misshapen trophozoites of $S$. muris, but did not affect the cytoskeleton (Oxberry et al. 1994). Metronidazole at 5 ppm in water (Bassleer 1983, Gratzek 1983, Jenkins 1988) or at $10 \mathrm{mg}$ in $1.0 \mathrm{~g}$ of food (Stoskopf 1988) is recommended for the treatment of intestinal flagellates in fish. The present study showed that trophozoites of $S$. vortens were inhibited and misshapen in the cultures exposed to dimetridazole or metronidazole. This may have been caused by the toxicity of the intermediates accumulated in the cells and the reducing of cytoplasmic materials. It has been proposed that the toxicity of the intermediates is due to their interaction with DNA, decreasing the stability and integrity of DNA, and possibly with other macromolecules (Edwards 1980, Müller 1983). These radical anions generated within intact hydrogenosomes also may damage the radical-generating system and the hydrogenosome membrane, and are capable of efflux from isolated organelles (Chapman et al. 1985). The results of misshapen or damaged cell organelles may also lead to a failure of cell division. Thus, the large number of irregular, multinucleated trophozoites found in cultures exposed to dimetridazole and metronidazole may have been a result of cell division failure.

Trophozoites of Spironucleus vortens cultivated in medium with the benzimidazoles were also misshapen. However, the number of malformed trophozoites and multinucleated trophozoites were lower than those incubated with the nitroimidazoles. At the same concentration, mebendazole was more effective than albendazole and fenbendazole in inhibiting the growth of $S$. vortens. The effect of benzimidazoles on parasites is different from nitroimidazole in that the target of benzimidazole is a structure called $\beta$-tubulin (Edlind et al. 1990). Mebendazole has been shown to damage $\beta$-tubulin by distorting cell structures and rapidly disrupting the ventral disk and flagella of Giardia lamblia (Edlind et al. 1990), while albendazole binding to the cytoskeletal proteins causes trophozoites of $G$. duodenalis to become swollen, misshapen with cytoplasmic dark granule materials and finally die (Oxberry et al. 1994). Albendazole also increased glycogen granules and cytoplasmic vesicles and caused thickening of the parasite's cell coat with many invaginations (Oxberry et al. 1994). However, albendazole had no effect on the cytoskeleton or any other gross morphological characteristics of $S$. muris (Oxberry et al. 1994).

Pyrimethamine is most widely used clinically as an antimalarial chemotherapeutic agent (Pratt \& Fekety 1986). The drug has a parasiticidal effect by inhibiting the process of cell division. In the present study, pyrimethamine was examined for its efficacy on the growth of an energetic flagellated diplomonad, Spironucleus vortens. The results indicated that pyrimethamine did not affect the cell division of trophozoites. It is suggested that the parasites may not need the coenzyme, tetrahydrofolate, in the cell division process or the parasites may have alternative pathways that help in purine, pyrimidine and amino acid synthesis. 
Magnesium sulfate (Epsom salt) minimally affected the parasite's growth at low concentrations but inhibited growth at concentrations higher than $60 \mathrm{mg} \mathrm{ml}^{-1}$. It is suggested that magnesium sulfate at high concentration may interfere with homeostasis of ions between the inside and the outside of the cell. Further information about the mechanism of action of pyrimethamine and magnesium sulfate on diplomonads is needed.

Of the 7 chemotherapeutic agents investigated in this study, dimetridazole, metronidazole and mebendazole were the most effective compounds in vitro at inhibiting the growth of Spironucleus vortens. However, the success of individual treatments was dependent on both drug concentration and time of exposure.

Acknowledgements. The authors wish to express thanks to Dr David S. Lindsay for providing advice and some of the chemicals used in this research, and to Dr Sarah L. Poynton for encouragement and invaluable insight into this research.

\section{LITERATURE CITED}

Amon I, Amon K, Hüller H (1978) Pharmacokinetics and therapeutic efficacy of metronidazole at different dosages. Int J Clin Pharmacol Biopharm 16:384-386

Baines EJ (1978) Metronidazole: its past, present and future. J Antimicrob Chemother 4:97-111

Bassleer G (1983) Disease prevention and control. Freshw Mar Aquar 6:38-41, 58-60

Bell CA, Dykstra CC, Naiman NA, Cory M, Fairley TA, Tidwell RR (1993) Structure-activity studies of dicationically substituted bis-benzimidazoles against Giardia lamblia: correlation of antigiardial activity with DNA binding affinity and giardial topoisomerase Il inhibition. Antimicrob Agents Chemother 37:2668-2673

Bradyley SG, Marciano-Cabral F (1995) Antiparasitic drugs. In: Munson PL, Mueller RA, Breese GR (eds) Principles of pharmacology. Basic concepts and clinical applications. Chapman \& Hall, New York, p 1437-1473

Catchpool JF (1980) Antiprotozoal drugs. In: Meyers FH, Jawetz E, Goldfien A (eds) Review of medical pharmacology. Lange Medical Publications, Los Altos, CA, p 619-64.6

Chapman A, Cammack R, Linstead D, Lloyd D (1985) The generation of metronidazole radicals in hydrogenosomes isolated from Trichomonas vaginalis. J Gen Microbiol 131: $2141-2144$

Church DL, Bryant RD, Sim V, Laishley E.J (1996) Metronidazole susceptibility and the presence of hydrogenase in pathogenic bacteria. Anaerobe 2:147-153

Edlind TD, Hang TL, Chakraborty PR (1990) Activity of the anthelmintic benzimidazoles against Giardia lamblia in vitro. J Infect Dis 162:1408-1411

Edwards DI (1980) Mechanisms of selective toxicity of metronidazole and other nitroimidazole drugs. Br J Vener Dis $56: 285-290$

Ferguson HW (1979) Scanning and transmission electron

Editorial responsibility: Wolfgang Körting,

Hannover, Germany microscopical observations on Hexamita salmonis (Moore, 1992) related to mortalities in rainbow trout fry Salmo gairdneri Richardson. J Fish Dis 2:57-67

Gratzek JB (1983) Control and therapy of fish diseases. Adv Vet Sci Comp Med 27:297-324

Gratzek JB (1988) Tropical fish medicine. Parasites associated with ornamental fish. Vet Clin North Am Small Anim Pract 18:375-399

Jenkins WL (1988) Drugs affecting gastrointestinal functions. In: Broth $\mathrm{NH}$, Mcdonald LE (eds) Veterinary pharmacology and therapeutics. Iowa State University Press, Ames, p $657-671$

Kulda J, Lom J (1964) Remarks on the diplomastigine flagellates from the intestine of fishes. Parasitology 54:753-762

Lom J, Dyková I (1992) Developments in aquaculture and fisheries science, Vol 26. Protozoan parasites of fishes. Elsevier Science Publishers BV, New York, p 65-68

McElwain IB (1968) Efficacy of cyzine for trout hexamitiasis Prog Fish-Cult 30:84-91

McLean AJ, Ioannides-Demos LL, Spicer WJ (1984) Current clinical applications and dose regimens of metronidazole and related nitroimidazoles. Med J Aust 141:163-166

Mo TA, Poppe TT, lversen L (1990) Systemic hexamitosis in salt-water reared Atlantic salmon (Salmo salar L.). Bull Eur Assoc Fish Pathol 10:69-70

Molnár K (1974) Data on the 'octomitosis' (spironucleosis) of cyprinids and aquary fishes. Acta Vet Acad Sci Hung 24: 99-106

Müller M (1983) Mode of action of metronidazole on anaerobic bacteria and protozoa. Surgery 93:165-171

Oxberry ME, Thompson RC, Reynoldson JA (1994) Evaluation of the effects of albendazole and metronidazole on the ultrastructure of Giardia duodenalis, Trichomonas vaginalis and Spironucleus muris using transmission electron microscopy. Int J Parasitol 24:695-703

Poynton SL, Fraser W, Francis-Floyd R, Rutledge P, Reed P, Nerad TA (1995) Spironucleus vortens $\mathrm{n}$. $\mathrm{sp}$. from the freshwater angelfish Pterophyllum scalare: morphology and culture. J Eukaryot Microbiol 42:731-742

Pratt WB, Fekety R (1986) The antimicrobial drugs. Oxford University Press, New York, p 374-436

Rosenblatt JE (1992) Antiparasitic agents. Mayo Clin Proc 67 $276-287$

Sommerville C (1981) Parasites of ornamental fish. J Small Anim Pract 22:367-376

Stoskopf MK (1988) Tropical fish medicine. Fish chemotherapeutics. Vet Clin North Am Small Anim Pract 18:331-348

Tojo JL, Santamarina MT (1998) Oral pharmacological treatments for parasitic diseases of rainbow trout Oncorhynchus mykiss. I. Hexamita salmonis. Dis Aquat Org 33 $51-56$

Trier JS, Moxey PC, Schimmel EM, Robles E (1974) Chronic intestinal coccidiosis in man: intestinal morphology and response to treatment. Gastroenterology 66:923-935

Woo PTK, Poynton SL (1995) Diplomonadida, kinetoplastida and amoebida (Phylum Sarcomastigophora). In: Woo PTK (ed) Fish diseases and disorders 1. Protozoan and metazoan infections. Commonwealth Agriculture Bureau International, Wallingford

Yasutake WT, Buhler DR, Shanks WE (1961) Chemotherapy of hexamitiasis in fish. J Parasitol 47:81-86

Submitted: April 23, 1999; Accepted: June 4, 1999

Proofs received from author(s): September 13,1999 